\title{
Testing allometric scaling relationships in plant roots
}

\author{
Qiang Deng ${ }^{1,2}$, Zhiyou Yuan ${ }^{1,3^{*}}$, Xinrong Shi ${ }^{1,3}$, T. Ryan Lock ${ }^{4}$ and Robert L. Kallenbach ${ }^{4}$
}

\begin{abstract}
Background: Metabolic scaling theory predicts that plant productivity and biomass are both size-dependent. However, this theory has not yet been tested in plant roots.

Methods: In this study, we tested how metabolic scaling occurs in plants using a comprehensive plant root dataset made up of 1016 observations from natural habitats. We generated metabolic scaling exponents by logtransformation of root productivity versus biomass.

Results: Results showed that the metabolic scaling exponents of fine root ( $<2 \mathrm{~mm}$ in diameter) productivity versus biomass were close to 1.0 for all ecosystem types and functional groups. Scaling exponents decreased in coarse roots ( $>2 \mathrm{~mm}$ in diameter).

Conclusions: We found isometric metabolic scaling in fine roots, a metabolically active organ similar to seedlings or saplings. Our findings also indicate a shift in metabolic scaling during plant development. Overall, our study supports the absence of any unified single constant scaling exponent for metabolism-biomass relationships in terrestrial plants, especially for forests with woody species.
\end{abstract}

Keywords: Allometry, Biomass, Metabolic scaling, Plant roots, Productivity

\section{Introduction}

Many theories suggest that plant and animal body sizes scale with fundamental characteristics, such as metabolic rate (West et al. 1997, 2001; Enquist et al. 2002; O'Connor and Bernhardt 2018; Burger et al. 2019; Pettersen et al. 2019). The scaling relationship is determined by the power function:

$$
Y=Y_{0} X^{b}
$$

where $Y$ is an attribute, in this case, metabolic rate, $Y_{0}$ is a normalization constant (antilog of the intercept in a log$\log$ plot), and $b$ is the scaling exponent (slope in a log-log plot). The metabolic scaling exponent $b$ was once widely

\footnotetext{
* Correspondence: zyyuan@ms.iswc.ac.cn

${ }^{1}$ State Key Laboratory of Soil Erosion and Dryland Farming on the Loess Plateau, Institute of Soil and Water Conservation, Chinese Academy of Sciences and Ministry of Water Resources, Yangling 712100, Shaanxi, China ${ }^{3}$ Institute of Soil and Water Conservation, Northwest A\&F University, Yangling 712100, Shaanxi, China

Full list of author information is available at the end of the article
}

considered to be $2 / 3$, based on studies of differently sized dogs (Rubner 1883). However, Kleiber (1932), found that $b$ for metabolic scaling was closer to $3 / 4$ in 1932. Kleiber's law, or the 3/4-power law, is still widely used and supported by many metabolic studies showing quarter-power scaling for many animals, plants, and single cells (Beuchat 1997; Oviedo et al. 2003; West and Brown 2005; da Silva et al. 2006; Nidzieko 2018; Yoshikawa et al. 2019). Allometric scaling relationships are not only found in metabolic rates, but also other biological, chemical, ecophysiological and physical traits in animals and plants (Enquist et al. 1998; Glazier 2006; Strauss and Reinhold 2010; Slot et al. 2014; Yuan and Chen 2015; Ballesteros et al. 2018).

According to the metabolic theory of ecology that predicts a nonlinear power law for NPP scaling based on an ideally and fractally vascular system (i.e., NPP $=a \times$ (biomass) $^{b}$ ) (Enquist et al. 1998; West et al. 1999; Niklas and Enquist 2001; Brown et al. 2004; Enquist et al. 2009; West et al. 2009), a linear model (i.e., $\operatorname{logNPP}=a+$ $b \times(\log ($ biomass $))$ can describe this relationship in $\log -$ 
$\log$ space when using $(\log \mathrm{NPP}) /(\log \mathrm{B})$ axes that are standard in allometry. Similar to biogeographical species-area and productivity-diversity relationships, allometric scaling research based on the metabolic theory initially focused on bivariate power laws and then argued about a theoretically ideal (or canonical) power law exponent $b$. More recently, multiple predictor variables have been rapidly evolved to be recognized because the coefficient $a$ and other predictors are also important to their respective response variables (Rosenzweig 1995; Lomolino 2000; Jenkins and Pierce 2017).

However, the universal application of Kleiber's law is contested (Brown et al. 2005; da Silva and Barbosa 2009; Glazier 2010; Hamilton et al. 2011; Glazier 2014; Yates et al. 2020). For example, Kozłowski and Konarzewski (2004) argue that Kleiber's law cannot be explained using any limiting factor because metabolic rates vary by factors of 4-5 between rest and activity. Also, Reich et al. (2006) demonstrated that the dark respiration rate in whole seedlings scales isometrically with plant mass, showing that the allometric Kleiber's law cannot be extended to vascular plants. Li et al. $(2005,2006)$ asserted that there is no sufficient evidence to support the existence of a single constant scaling exponent for the metabolism-biomass relationship for terrestrial plants. However, most studies of metabolic scaling in vascular plants are based on aboveground parts, and much less is known about plant roots, which are important to the ecosystem but difficult to measure (Hanson et al. 2000; Sibly et al. 2012; Starko and Martone 2016; Jenkins and Pierce 2017; Minden et al. 2018; Ogawa 2019).

Like other plant organs, roots scale according to metabolic, chemical, and structural traits, in a manner sometimes consistent with animal scaling (Niklas 2006; Reich et al. 2006; Marba et al. 2007; Hamilton et al. 2011; Rudgers et al. 2019). Roots are metabolically active organs expected to scale according to Kleiber's law. For example, fine root productivity may allometrically scale with biomass, because fine root productivity is dictated by metabolic rate and often serves as a surrogate measure for fine root metabolic rate (West et al. 1999; Niklas and Enquist 2001; Enquist and Niklas 2002). Importantly, due to different morphology, compared with stems and leaves plant root systems are more like "open network", water and nutrient uptake can occur along any part of the root network (Biondini 2008). Therefore, the scaling exponent in roots is unlikely to be the same as for aboveground parts. Additionally, root productivity and plant biomass both change across soil environments at local and global scales (Vogt et al. 1998; Hertel and Leuschner 2002; Yuan and Chen 2012a; Yuan and Chen 2012b; Yuan et al. 2018). However, it is unknown whether plant root productivity allometrically scales with biomass or if the allometric scaling exponent would follow the 3/4-power law.
Plant roots show both similarity and difference in comparison to aboveground parts. Terrestrial productivity is greatest in lowland tropical forests near the equator and declines toward the temperate regions to the north or south (Huston and Wolverton 2009; Yuan et al. 2011). Given that plant roots, particularly fine roots $<2 \mathrm{~mm}$ in diameter, are a significant proportion of total plant productivity (Nadelhoffer and Raich 1992; Vogt et al. 1996; Clark et al. 2001; Yuan and Chen 2010), root productivity is expected to vary similarly to aboveground productivity. However, global patterns of root productivity are unclear. For instance, fine root biomass is high in grasslands but low in forests (Jackson et al. 1997; Schenk and Jackson 2002; Cleland et al. 2019). Furthermore, fine root productivity and biomass differ between life forms (Bauhus and Messier 1999; Pavon 2005). The differences between biomes and life forms suggest that plant root productivity and biomass depend on organism size. However, no studies have tested whether scaling between plant root productivity and biomass changes across ecosystems and life forms. Here, we examined how plant root productivity scales with biomass by compiling 327 published reports with 826 estimates of root productivity and biomass that cover the global terrestrial ecosystem.

\section{Materials and methods}

To examine the relationship between root biomass and production in natural habitats, we searched the keywords "plant roots, biomass, production/productivity" in the Web of Science database (1965-2020) to retrieve relevant data for our meta-analysis using the following inclusion criteria: (1) reported at least one parameter including plant roots or belowground biomass, production; (2) included the mean, standard deviation or error, and sample size of reported parameters; and (3) reported the measurements of roots biomass and production, and defined/described the ecosystem types, life forms, leaf phenology and phylogeny of the experimental site. We used Image-Pro Plus (Media Cybernetics, Rockville, Maryland, USA) to extract numerical data

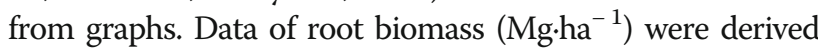
from direct measurement via soil coring. Data for estimating root production $\left(\mathrm{Mg} \cdot \mathrm{ha}^{-1} \cdot \mathrm{year}^{-1}\right)$ were derived from eleven methods: ingrowth, minirhizotrons, max-min, decision matrix, sum of all positive changes, sum of significant positive changes, compartment-flow model, $\mathrm{N}$ budget, $\mathrm{C}$ budget, isotopic and correlation methods. To avoid those using root biomass as a proxy for root production, we excluded the data of estimating root production by correlation methods. Thus the variables of root biomass and production in our dataset were independent from each other.

Our dataset included 1016 observations compiled from 327 published studies of plant root productivity and biomass in natural habits. The dataset excluded agricultural, fertilized, and greenhouse studies (a list of the data 
Table 1 Fine root biomass, productivity (Mean \pm 1 S.E. with range in parentheses), and number of samples ( $n$ ) for plant groups by ecosystem types, life forms, leaf phenology, and phylogeny. Differences between ecosystem types are tested using a one-way ANOVA with a Tukey's post hoc test for significance. Significant differences $(a=0.05)$ are indicated by different letters

\begin{tabular}{|c|c|c|c|}
\hline Plant groups & Biomass $\left(\mathrm{Mg} \cdot \mathrm{ha}^{-1}\right)$ & Productivity $\left(\mathrm{Mg} \cdot \mathrm{ha}^{-1} \cdot \mathrm{yr}^{-1}\right)$ & $n$ \\
\hline \multicolumn{4}{|l|}{ Ecosystem types } \\
\hline Boreal forests & $2.23^{B} \pm 0.14(0.04-10.70)$ & $2.72^{\mathrm{C}} \pm 0.17(0.12-14.19)$ & 184 \\
\hline Temperate forests & $3.19^{B} \pm 0.21(0.02-30.00)$ & $2.81^{C} \pm 0.22(0.07-35.09)$ & 254 \\
\hline Subtropical forests & $2.84^{B} \pm 0.27(0.08-14.48)$ & $2.61^{C} \pm 0.24(0.05-10.40)$ & 101 \\
\hline Tropical forests & $3.54^{B} \pm 0.29(0.19-20.58)$ & $2.98^{\complement} \pm 0.27(0.06-20.84)$ & 118 \\
\hline Temperate grasslands & $10.10^{\mathrm{A}} \pm 1.64(0.32-65.70)$ & $4.87^{B C} \pm 0.83(0.21-29.31)$ & 50 \\
\hline Tropical grasslands & $8.71^{\mathrm{A}} \pm 1.83(1.22-24.00)$ & $6.97^{\mathrm{AB}} \pm 1.33(3.06-15.92)$ & 12 \\
\hline Tundra & $9.75^{\mathrm{A}} \pm 2.85(0.23-28.25)$ & $6.66^{\mathrm{AB}} \pm 1.77(0.36-19.70)$ & 16 \\
\hline Wetlands & $8.97^{A} \pm 1.19(0.04-49.01)$ & $8.03^{\mathrm{A}} \pm 1.24(0.10-54.45)$ & 91 \\
\hline \multicolumn{4}{|l|}{ Life forms } \\
\hline Forbs & $14.35^{\mathrm{A}} \pm 8.31(0.70-40.60)$ & $10.55^{\mathrm{A}} \pm 5.58(1.00-29.17)$ & 5 \\
\hline Graminoids & $11.62^{\mathrm{A}} \pm 1.17(0.04-65.70)$ & $8.76^{\mathrm{A}} \pm 1.09(0.10-54.45)$ & 103 \\
\hline Shrubs & $10.61^{\mathrm{A}} \pm 2.52(0.36-28.25)$ & $7.58^{\mathrm{A}} \pm 1.67(1.02-19.70)$ & 16 \\
\hline Trees & $2.95^{\mathrm{B}} \pm 0.11(0.02-30.00)$ & $2.74^{B} \pm 0.11(0.05-35.09)$ & 702 \\
\hline \multicolumn{4}{|l|}{ Leaf phenology } \\
\hline Deciduous & $6.35^{\mathrm{A}} \pm 0.48(0.04-65.71)$ & $4.81^{\mathrm{A}} \pm 0.41(0.05-54.45)$ & 333 \\
\hline Evergreen & $3.85^{\mathrm{B}} \pm 0.25(0.02-54.92)$ & $2.84^{B} \pm 0.14(0.04-35.09)$ & 493 \\
\hline \multicolumn{4}{|l|}{ Phylogeny } \\
\hline Angiosperm & $5.34^{\mathrm{A}} \pm 0.34(0.04-65.71)$ & $4.18^{\mathrm{A}} \pm 0.27(0.05-54.45)$ & 497 \\
\hline Gymnosperm & $2.59^{B} \pm 0.14(0.02-15.00)$ & $2.79^{B} \pm 0.16(0.11-35.09)$ & 329 \\
\hline All & $4.24 \pm 0.22(0.02-65.71)$ & $3.63 \pm 0.19(0.04-54.45)$ & 826 \\
\hline
\end{tabular}

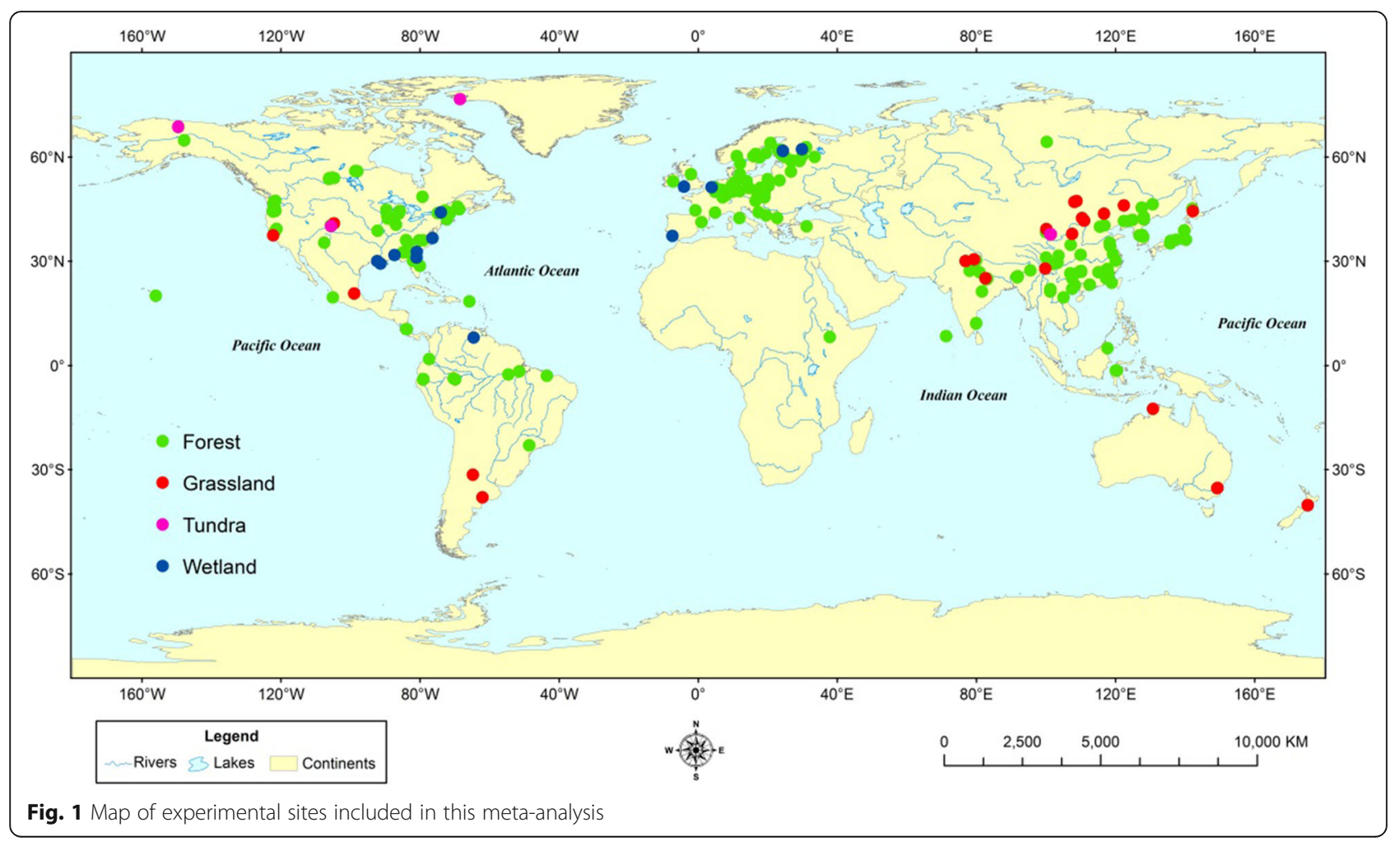




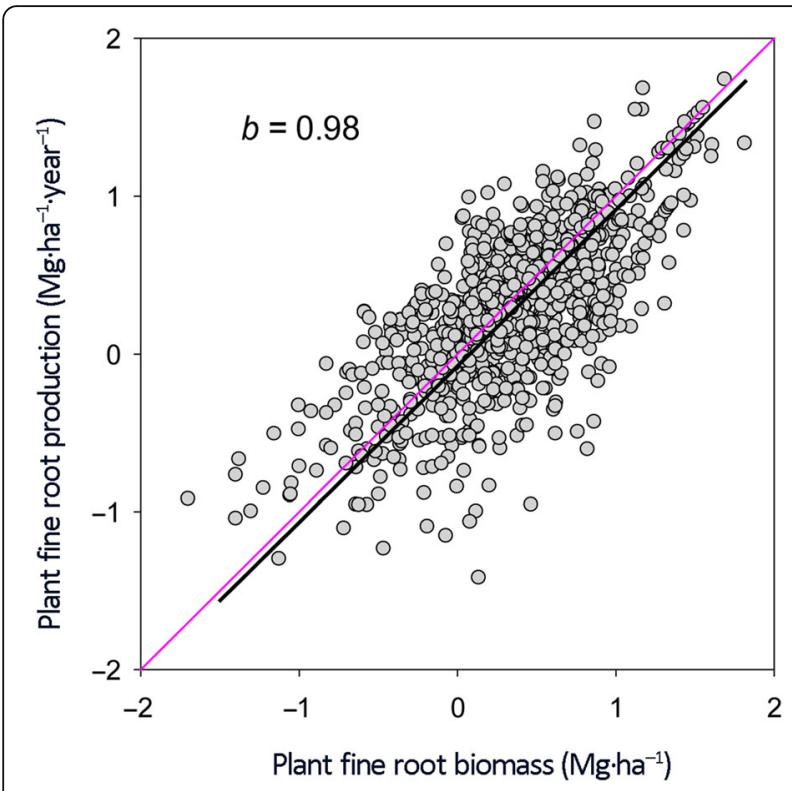

Fig. 2 SMA results of the relationship between plant fine root productivity $(P)$ and biomass $(M)$ at a global scale. Values are log-transformed (base 10). The line shows the fitted regression equation $\log _{10} P=-0.080+0.98 \times$ $\log _{10} M\left(95 \%\right.$ C.l. for slope is 0.93 to $\left.1.03, r^{2}=0.51, n=826\right)$. The short dash lines refer to the $95 \%$ confidence intervals. The pink line refers to the 1:1 line sources is found in the Electronic Supplementary Material). The combined data represented 257 sites and covered a wide range of ecosystems, including arctic tundra, forest, grassland, and wetland (Fig. 1). We further classified forests into four types: boreal, temperate, subtropical, and tropical. Site elevation ranged from 5 to $3600 \mathrm{~m}$ above sea level and latitude ranged from $-40^{\circ} \mathrm{S}$ to $76^{\circ} \mathrm{N}$. Mean annual temperature ranged from $-11^{\circ} \mathrm{C}$ to $27^{\circ} \mathrm{C}$ and mean annual rainfall ranged from 120 to $10,370 \mathrm{~mm}$ per year, covering most areas with a natural distribution of plants (Table 1 and supporting information (SI)). The broad coverage of the dataset allowed us to quantify scaling relationships between root productivity and plant biomass. Plant roots were classified into fine roots $(<2$ $\mathrm{mm}$ in diameter) and coarse roots ( $>2 \mathrm{~mm}$ in diameter).

We $\log 10$-transformed the data for root productivity and biomass. Normality tests were performed on the transformed data. When neither root productivity or biomass could be clearly separated into independent or dependent categories, we used reduced major axis regression (RMA), a Model II regression method (Rohlf and Sokal 1981), to characterize scaling relationships. We performed Model II regression analysis in $\mathrm{R}$ using the LMODEL2 package (Legendre 2008). Two-tailed $t$ tests determined whether slopes were significantly

Table 2 Summary of model II (reduced major axis) regressions of $\log _{10^{-}}$fine-root productivity $(y)$ and -biomass $(x)$ by ecosystem types, life forms, leaf phenology, and phylogeny. $n$ is the number of samplings

\begin{tabular}{|c|c|c|c|c|c|c|}
\hline Biome & Intercept & $95 \% \mathrm{Cl}$ intercept & Slope & $95 \% \mathrm{Cl}$ slope & $r^{2}$ & $n$ \\
\hline \multicolumn{7}{|l|}{ Ecosystem types } \\
\hline Boreal forests & 0.082 & $0.108 \sim 0.053$ & 1.003 & $0.833 \sim 1.139$ & 0.238 & 184 \\
\hline Temperate forests & -0.036 & $-0.057 \sim-0.015$ & 0.930 & $0.853 \sim 1.015$ & 0.511 & 254 \\
\hline Subtropical forests & -0.125 & $-0.177 \sim-0.080$ & 1.112 & $0.958 \sim 1.292$ & 0.433 & 101 \\
\hline Tropical forests & -0.131 & $-0.203 \sim-0.068$ & 1.078 & $0.923 \sim 1.258$ & 0.286 & 118 \\
\hline Temperate grasslands & -0.279 & $-0.417 \sim-0.166$ & 0.938 & $0.780 \sim 1.128$ & 0.594 & 50 \\
\hline Tropical grasslands & 0.166 & $-0.287 \sim 0.423$ & 0.731 & $0.415 \sim 1.284$ & 0.287 & 12 \\
\hline Tundra & -0.085 & $-0.212 \sim 0.020$ & 0.944 & $0.774 \sim 1.151$ & 0.878 & 16 \\
\hline Wetlands & -0.149 & $-0.197 \sim-0.105$ & 1.026 & $0.944 \sim 1.115$ & 0.843 & 91 \\
\hline \multicolumn{7}{|l|}{ Life forms } \\
\hline Forbs & 0.238 & $-0.350 \sim 0.496$ & 0.738 & $0.323 \sim 1.685$ & 0.747 & 5 \\
\hline Graminoids & -0.036 & $-0.140 \sim 0.082$ & 0.928 & $0.814 \sim 1.057$ & 0.850 & 38 \\
\hline Shrubs & 0.043 & $-0.125 \sim 0.176$ & 0.828 & $0.655 \sim 1.047$ & 0.829 & 16 \\
\hline Trees & -0.050 & $-0.068 \sim-0.035$ & 1.026 & $0.969 \sim 1.087$ & 0.400 & 702 \\
\hline \multicolumn{7}{|l|}{ Leaf phenology } \\
\hline Deciduous & -0.135 & $-0.165 \sim-0.105$ & 0.983 & $0.920 \sim 1.050$ & 0.626 & 333 \\
\hline Evergreen & -0.011 & $-0.031 \sim 0.008$ & 1.010 & $0.942 \sim 1.082$ & 0.387 & 493 \\
\hline \multicolumn{7}{|l|}{ Phylogeny } \\
\hline Angiosperm & -0.136 & $-0.162 \sim-0.111$ & 1.016 & $0.959 \sim 1.077$ & 0.564 & 497 \\
\hline Gymnosperm & 0.046 & $0.028 \sim 0.063$ & 0.967 & $0.890 \sim 1.050$ & 0.418 & 329 \\
\hline All & -0.080 & $-0.121 \sim-0.039$ & 0.980 & $0.934 \sim 1.029$ & 0.508 & 826 \\
\hline
\end{tabular}




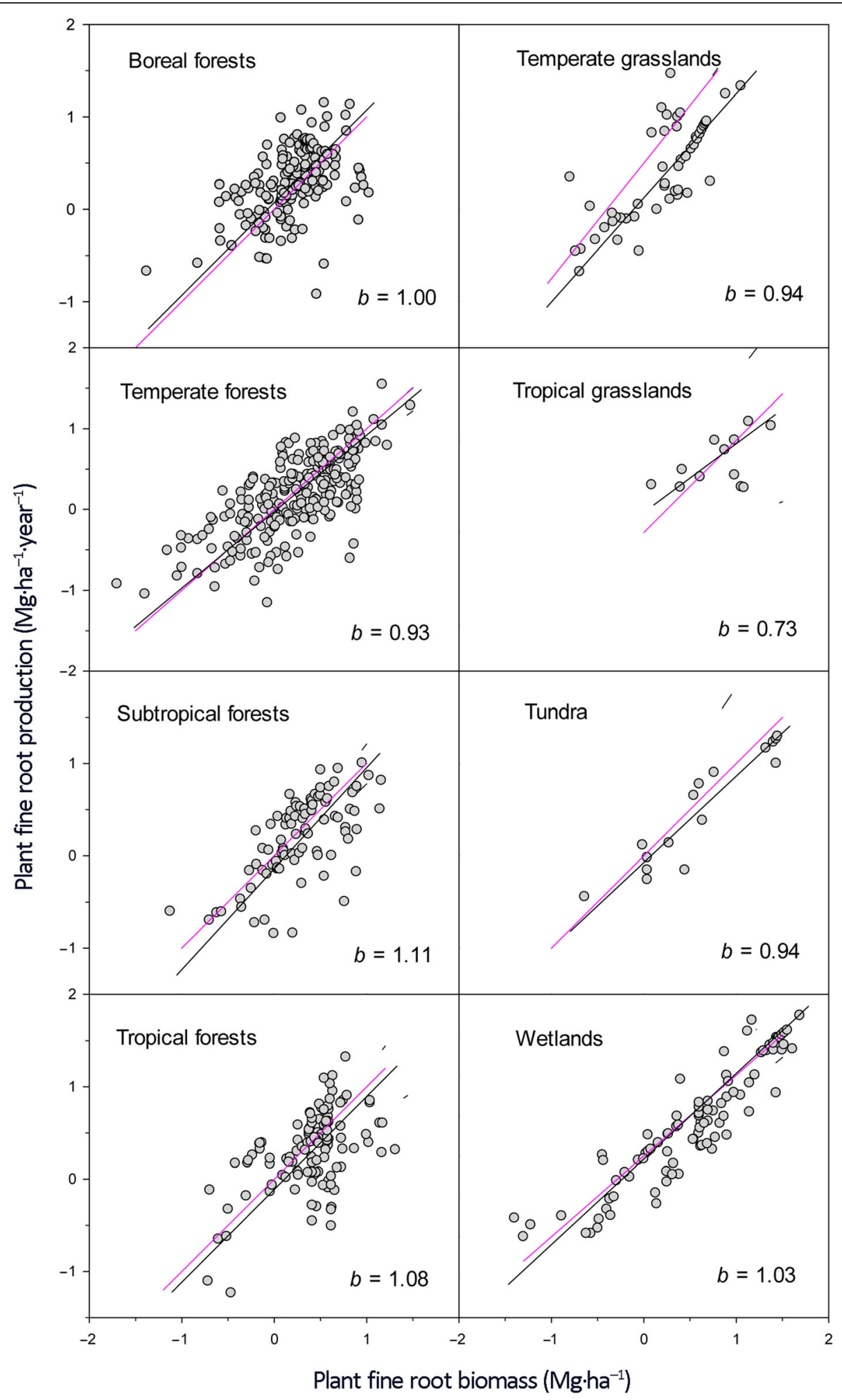

Fig. 3 (See legend on next page.) 
(See figure on previous page.)

Fig. 3 SMA results of the relationship between plant fine root productivity $(P)$ and biomass $(M)$ among ecosystems. Values are log-transformed (base 10). The lines show the fitted regression equations for boreal forests: $\log _{10} P=0.082+1.00 \times \log _{10} M\left(95 \%\right.$ C.I. for slope is 0.83 to $1.14, r^{2}=$ $0.24, n=184)$; temperate forests: $\log _{10} P=-0.036+0.93 \times \log _{10} M\left(95 \%\right.$ C.I. for slope is 0.85 to $\left.1.02, r^{2}=0.51, n=254\right)$; subtropical forests: $\log _{10} P=$ $-0.125+1.11 \times \log _{10} M\left(95 \%\right.$ C.I. for slope is 0.96 to $\left.1.29, r^{2}=0.43, n=101\right)$; tropical forests: $\log _{10} P=-0.131+1.08 \times \log _{10} M$ ( $95 \%$ C.I. for slope is 0.92 to $\left.1.26, r^{2}=0.29, n=118\right)$; temperate grasslands: $\log _{10} P=-0.279+0.94 \times \log _{10} M\left(95 \%\right.$ C.I. for slope is 0.78 to $\left.1.13, r^{2}=0.59, n=50\right)$; tropical grasslands: $\log _{10} P=0.166+0.73 \times \log _{10} M\left(95 \%\right.$ C.I. for slope is 0.42 to $\left.1.28, r^{2}=0.29, n=12\right)$; tundra: $\log _{10} P=-0.085+0.94 \times \log _{10} M(95 \%$ C.I. for slope is 0.77 to $\left.1.15, r^{2}=0.88, n=16\right)$; wetlands: $\log _{10} P=-0.149+1.03 \times \log _{10} M\left(95 \%\right.$ C.I. for slope is 0.94 to $\left.1.12, r^{2}=0.84, n=91\right)$. The short dash lines refer to the $95 \%$ confidence intervals. The pink line refers to the $1: 1$ line

different from the number 1 . All statistical analyses were performed in $\mathrm{R}$ version 3.62 for Windows.

\section{Results}

When we pooled all data $(n=826)$, we found that fine root

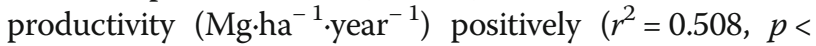

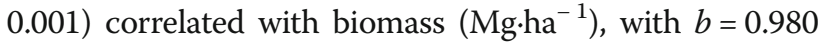
(95\% CI of $b=0.934-1.027, \log _{10} Y_{0}=-0.055$ ). The analysis was based on a reduced major axis (RMA) regression of $\log$ transformed Eq. 1 (Fig. 2). The value of $b$ was not significantly different from 1.0. Slope estimates generated by ordinary least squares (OLS) or standard major axis
(SMA) did not differ from estimates generated by RMA. We further analyzed the scaling relationships of fine root productivity versus biomass across ecosystem types and plant functional groups. We found that the scaling slope was consistent across most ecosystem types (except for tropical grasslands), with $b$ close to 1.0 with $95 \%$ CIs (Table 2, Fig. 3), and among major functional groups, the scaling exponents of $b$ were again close to 1.0 with $95 \%$ CIs for graminoids and trees (Fig. 4).

Because large samples from forests were obtained, we also compared scaling slopes between leaf phenology and phylogeny in forest ecosystems (Fig. 5). We again

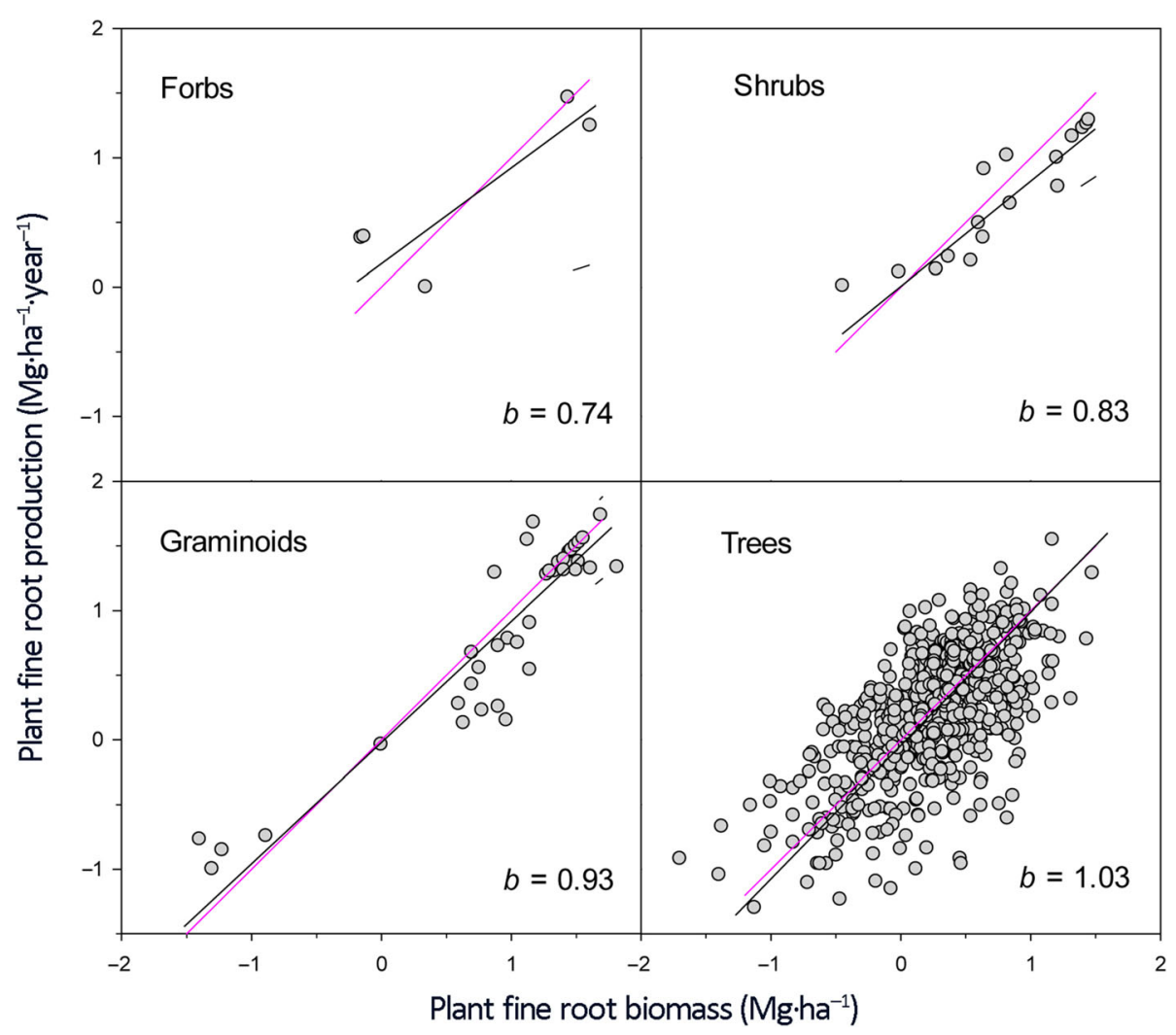

Fig. 4 SMA results of the relationship between plant fine root productivity $(P)$ and biomass $(M)$ among life forms. Values are log-transformed (base 10). The lines show the fitted regression equations for forbs: $\log _{10} P=0.238+0.74 \times \log _{10} M\left(95 \%\right.$ C.I. for slope is 0.32 to $1.69, r^{2}=0.75, n=5$ ); graminoids: $\log _{10} P=-0.036+0.93 \times \log _{10} \mathrm{M}\left(95 \%\right.$ C.I. for slope is 0.81 to $\left.1.06, r^{2}=0.85, n=38\right)$; shrubs: $\log _{10} P=0.043+0.83 \times \log _{10} \mathrm{M}(95 \%$ C.I. for slope is 0.66 to $\left.1.05, r^{2}=0.83, n=16\right)$; trees: $\log _{10} P=-0.050+1.03 \times \log _{10} M\left(95 \%\right.$ C.I. for slope is 0.97 to $\left.1.09, r^{2}=0.40, n=702\right)$. The short dash lines refer to the $95 \%$ confidence intervals. The pink line refers to the $1: 1$ line 


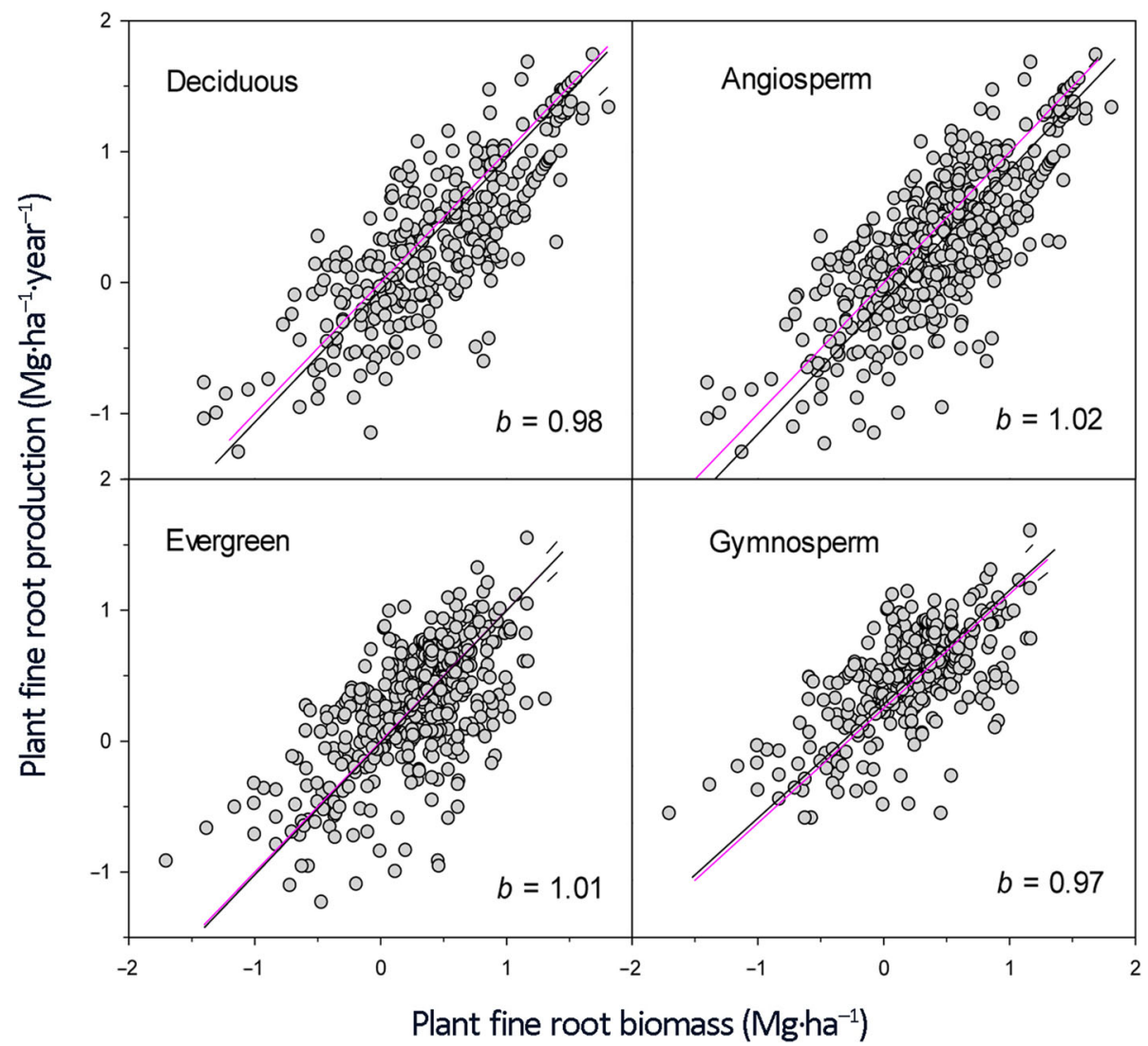

Fig. 5 SMA results of the relationship between plant fine root productivity $(P)$ and biomass $(M)$ for plants with different leaf phenology and phylogeny. Values are log-transformed (base 10). The lines show the fitted regression equations for deciduous species: $\log _{10} P=-0.135+0.98 \times \log _{10} M(95 \%$ C.I. for slope is 0.92 to $\left.1.05, r^{2}=0.63, n=333\right)$; evergreen species: $\log _{10} P=-0.011+1.01 \times \log _{10} M\left(95 \%\right.$ C.I. for slope is 0.94 to $\left.1.08, r^{2}=0.38, n=493\right)$; angiosperm species: $\log _{10} P=-0.136+1.02 \times \log _{10} M$ (95\% C.I. for slope is 0.96 to $\left.1.08, r^{2}=0.56, n=497\right)$; gymnosperm species: $\log _{10} P=0.046+0.97 \times \log _{10} M(95 \%$ C.I. for slope is 0.89 to $1.05, r^{2}=0.42, n=329$ ). The short dash lines refer to the $95 \%$ confidence intervals. The pink line refers to the $1: 1$ line

found that results for RMA regression for fine root productivity-biomass scaling (Table 2) had a scaling exponent $b$ near 1.0. However, the scaling relationships in coarse roots $(>2 \mathrm{~mm}$ in diameter) differed from fine roots $(<2 \mathrm{~mm}$ in diameter), such that the scaling exponent $b$ decreased from $\approx 1.0$ in fine roots to 0.86 in coarse roots (Table 3, Fig. 6).

\section{Discussion}

We found that the power law scaling exponent for plant fine root productivity versus biomass is close to 1.0 in many ecosystems (except for tropical grasslands with small data size), functional groups (except for forbs and shrubs with small data size), and two leaf phenology and phylogeny groups in forest ecosystems. The metabolic theory represents ideal systems and has been debated (Isaac and Carbone 2010; Glazier 2014, 2015). Lomolino (2000) first pointed out that it was problematic to use power law model to investigate all qualitative patterns in the nature, and the constant $Y_{0}$ was often neglected with respect to the exponent $b$. Nevertheless, $Y_{0}$ varied by orders of magnitudes for biogeographical species-area and productivity-diversity relationships. Our dataset were compiled with 1016 observations from various

Table 3 Summary of model II (reduced major axis) regressions of $\log _{10^{-}}$root productivity $(y)$ and root biomass $(x)$ by root sizes. $n$ is the number of samplings. Slopes statistically greater or smaller than $1(p<0.05)$ are indicated by boldface font

\begin{tabular}{lllllll}
\hline Root sizes & Intercept & 95\% Cl intercept & Slope & 95\% Cl slope & $\boldsymbol{r}^{\mathbf{2}}$ \\
\hline$<1 \mathrm{~mm}$ & 0.123 & $0.106 \sim 0.139$ & 0.914 & $0.803 \sim 1.041$ & 0.539 & $\mathbf{n}$ \\
$1-2 \mathrm{~mm}$ & -0.227 & $-0.298 \sim-0.164$ & 1.009 & $0.901 \sim 1.129$ & 0.745 \\
$>2 \mathrm{~mm}$ & -0.178 & $-0.241 \sim-0.123$ & $\mathbf{0 . 8 7 8}$ & $0.784 \sim 0.986$ & 0.361 \\
All & -0.075 & $-0.103 \sim-0.047$ & $\mathbf{0 . 8 5 6}$ & $0.796 \sim 0.920$ & 0.486 & 380 \\
\hline
\end{tabular}




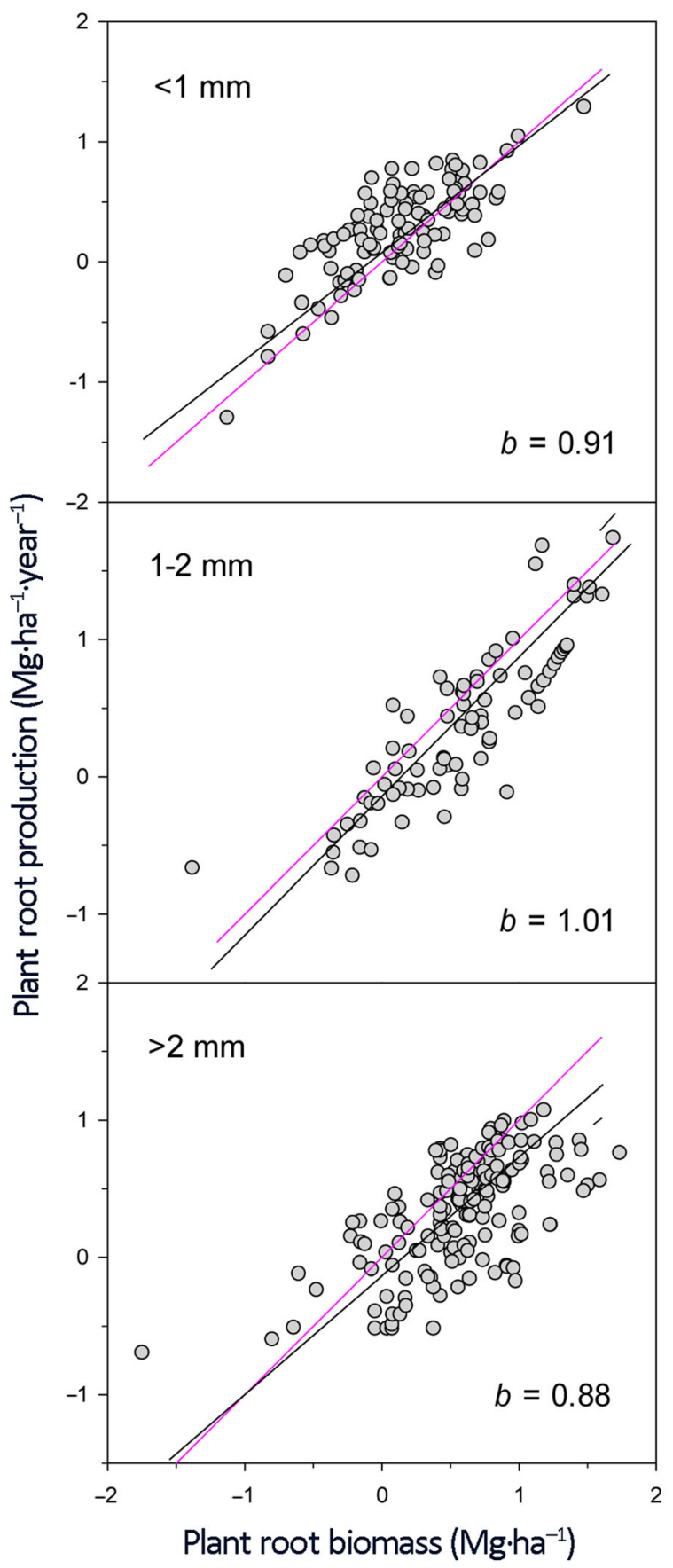

Fig. 6 SMA results of the relationship between plant fine root productivity $(P)$ and biomass $(M)$ for roots with different diameters. Values are logtransformed (base 10). The lines show fitted regression equations for fine roots of $<1 \mathrm{~mm}$ in diameter: $\log _{10} P=0.123+0.91 \times \log _{10} M(95 \%$ C.I. for slope is 0.80 to $\left.1.04, r^{2}=0.54, n=109\right)$; fine roots of $1-2 \mathrm{~mm}$ in diameter: $\log _{10} P=-0.227+1.01 \times \log _{10} \mathrm{M}\left(95 \%\right.$ C.I. for slope is 0.90 to $1.13, r^{2}=$ $0.75, n=81)$; coarse roots of $>2 \mathrm{~mm}$ in diameter: $\log _{10} P=-0.178+0.88 \times \log _{10} M\left(95 \%\right.$ C.I. for slope is 0.78 to $\left.0.99, r^{2}=0.36, n=190\right)$. The short dash lines refer to the $95 \%$ confidence intervals. The pink line refers to the 1:1 line

ecosystems all over the world, and all data analyses were conducted under the same order of magnitude. Therefore, we have continued to use only the power law model and focused on discussing exponent $b$. Our dataset included studies using various methods to measure production except using biomass as a proxy for production, which could cause error and the power law scaling exponent close to 1.0 (Jenkins 2015; Jenkins et al. 2020). Fine roots are metabolically active organs (Kerkhoff et al. 2006; Peng et al. 2010) with higher respiration rates than 
coarse roots (Pregitzer et al. 1998; Desrochers et al. 2002; Marsden et al. 2008). The higher respiration rate may contribute to the isometric scaling of plant fine root productivity with biomass. Additionally, gravity is relatively unimportant and space-filling is incomplete for fine roots with few branch levels (Enquist et al. 2007), resulting in the exponent $b \approx 1.0$. Our findings suggest that scaling relationships for fine roots may be similar to those in aboveground leaves, although no reports have yet studied the productivity-biomass scaling relationship in plant leaves. Although fine root productivity and biomass differed between biomes and life forms, our results revealed that there was no significant difference of the power law scaling exponent (except for tropical grasslands, forbs and shrubs with small data size), suggesting that a constant rule might exist.

We also found differences between fine roots and coarse roots. Animals transitioning from larval to adult stages undergo an ontogenetic scaling shift (Glazier 2005). For plants, metabolic scaling theory suggests an ontogenetic shift in scaling of plant respiration with body size from isometric $(b=1.0)$ to negatively allometric $(b<1.0)$ (Enquist et al. 2007; Reich et al. 2007; Savage et al. 2008; Lin et al. 2013; McCarthy et al. 2019). Measurements of whole plant respiration rates show that allometric exponents for the scaling of respiration rate with body size continuously vary from 1.0 in the smallest plants to $3 / 4$ in larger saplings and trees (Mori et al. 2010). Ontogenetic transition of plant characteristics occurs when young seedlings grow into mature trees (Bond 2000; Ryan et al. 2004; Ishida et al. 2005). Coarse roots are metabolically more inactive and have more massive structural components than fine roots (Kerkhoff et al. 2006). As roots grow, gravity becomes increasingly important and volume-filling architecture develops (West et al. 1999; Enquist et al. 2007). For these reasons, the $b=1.0$ allometric exponent for the productivity-biomass relationship in fine roots decreases in coarse roots, as we found in this analysis. Notably, we found the scaling exponent in coarse roots was close to 0.86 , and not $3 / 4$ as metabolic theory predicts.

In our dataset, coarse roots with diameters of $2-5 \mathrm{~mm}$ were about $95 \%$ of all coarse roots, suggesting that the observed scaling relationship in coarse roots is determined by these smaller roots. An ontogenetic transition in metabolic scaling would mean that the power-law scaling exponent for bigger coarse roots (> $5 \mathrm{~mm}$ diameter) would be near $3 / 4$. Therefore, the metabolic scaling relationships in fine and coarse roots are similar to those in their aboveground counterparts, i.e., leaves and stems, respectively. The scaling of dark respiration rate in roots (pooled for fine and coarse roots) in relation to tissue $\mathrm{N}$ concentration is similar to stems, but different than leaves (Reich et al. 2008; Fan et al. 2017). However, there is no data directly comparing productivity-biomass scaling between fine roots and green leaves.

\section{Conclusions}

Our analysis of the scaling of root productivity with biomass indicates that productivity in plant fine roots $(<2$ $\mathrm{mm}$ in diameter) scales isometrically with biomass. A gradual ontogenetic transition occurs when fine roots grow into coarse roots ( $>2 \mathrm{~mm}$ in diameter). This transition is also seen in the scaling of respiration with body size for young seedling growing into larger mature trees (Enquist et al. 2007; Mori et al. 2010; Starko and Martone 2016; Ogawa 2019; Collalti et al. 2020). Our findings support the idea that there is not a unified and single constant scaling exponent for metabolismbiomass relationships in terrestrial plants, consistent with the hypothesis by White (2010), which argues that no universal scaling exponent can be applied to animals and plants.

\section{Supplementary information}

Supplementary information accompanies this paper at https://doi.org/10. 1186/s40663-020-00269-6.

\section{Additional file 1.}

Additional file 2

\section{Authors' contributions}

ZY planned the project. QD undertook most of the literature review and analyzed the data. ZY and QD wrote the manuscript. XS contributed additional literature and contributed substantially to modifying the manuscript. TRL and RLK edited the language of this manuscript. All authors read and approved the final manuscript.

\section{Funding}

This study was supported by the National Key Research and Development Plan of China (2016YFA0600801), the Hundred Talents Program of Shaanxi Province (A289021701), the Natural Science Basic Research Plan in Shaanxi Province of China (2018JZ3002), the Special Fund from the State Key Laboratory of Soil Erosion and Dryland Farming on the Loess Plateau (A314021403-C9), and the Double First Class University Plan of NWSUAF (Z102021829).

Availability of data and materials Not applicable.

Ethics approval and consent to participate Not applicable.

\section{Consent for publication}

Not applicable.

\section{Competing interests}

The authors declare that they have no competing interests.

\section{Author details}

${ }^{1}$ State Key Laboratory of Soil Erosion and Dryland Farming on the Loess Plateau, Institute of Soil and Water Conservation, Chinese Academy of Sciences and Ministry of Water Resources, Yangling 712100, Shaanxi, China. ${ }^{2}$ University of Chinese Academy of Sciences, Beijing 100049, China. ${ }^{3}$ Institute of Soil and Water Conservation, Northwest A\&F University, Yangling 712100, Shaanxi, China. ${ }^{4}$ Division of Plant Sciences, College of Agriculture, Food, and Natural Resources, University of Missouri, 108 Waters Hall, Columbia, MO 65211, USA. 
Received: 27 February 2020 Accepted: 30 September 2020 Published online: 23 October 2020

\section{References}

Ballesteros FJ, Martinez VJ, Luque B, Lacasa L, Valor E, Moya A (2018) On the thermodynamic origin of metabolic scaling. Sci Rep 8:e1448

Bauhus J, Messier C (1999) Soil exploitation strategies of fine roots in different tree species of the southern boreal forest of eastern Canada. Can J For Res 29:260-273

Beuchat CA (1997) Allometric scaling laws in biology. Science 278:369-373

Biondini M (2008) Allometric scaling laws for water uptake by plant roots. J Theor Biol 251:35-59

Bond BJ (2000) Age-related changes in photosynthesis of woody plants. Trend Plant Sci 5:349-353

Brown JH, Gillooly JF, Allen AP, Savage VM, West GB (2004) Toward a metabolic theory of ecology. Ecology 85:1771-1789

Brown JH, West GB, Enquist BJ (2005) Yes, West, Brown and Enquist's model of allometric scaling is both mathematically correct and biologically relevant. Funct Ecol 19:735-738

Burger JR, Hou C, Brown JH (2019) Toward a metabolic theory of life history. PNAS 116:26653-26661

Clark DA, Brown S, Kicklighter DW, Chambers JQ, Thomlinson JR, Ni J (2001) Measuring net primary production in forests: concepts and field methods. Ecol Appl 11:356-370

Cleland EE, Lind EM, DeCrappeo NM, DeLorenze E, Wilkins RA, Adler PB, Bakker JD, Brown CS, Davies KF, Esch E, Firn J, Gressard S, Gruner DS, Hagenah N, Harpole WS, Hautier Y, Hobbie SE, Hofmockel KS, Kirkman K, Knops J, Kopp CW, La Pierre KJ, MacDougall A, McCulley RL, Melbourne BA, Moore JL, Prober SM, Riggs C, Risch AC, Schuetz M, Stevens C, Wragg PD, Wright J, Borer ET, Seabloom EW (2019) Belowground biomass response to nutrient enrichment depends on light limitation across globally distributed grasslands. Ecosystems 22:1466-1477

Collalti A, Tjoelker MG, Hoch G, Mäkelä A, Guidolotti G, Heskel M, Petit G, Ryan MG, Battipaglia G, Matteucci G (2020) Plant respiration: controlled by photosynthesis or biomass? Glob Chang Biol 26:1739-1753

da Silva JKL, Barbosa LA (2009) Non-universal interspecific allometric scaling of metabolism. Braz J Phys 39:699-706

da Silva JKL, Garcia GJM, Barbosa LA (2006) Allometric scaling laws of metabolism. Phys Life Rev 3:229-261

Desrochers A, Landhausser SM, Lieffers VJ (2002) Coarse and fine root respiration in aspen (Populus tremuloides). Tree Physiol 22:725-732

Enquist BJ, Allen AP, Brown JH, Gillooly JF, Kerkhoff AJ, Niklas KJ, Price CA, West GB (2007) Does the exception prove the rule? Nature 445:E9-E10

Enquist BJ, Brown JH, West GB (1998) Allometric scaling of plant energetics and population density. Nature 395:163-165

Enquist BJ, Niklas KJ (2002) Global allocation rules for patterns of biomass partitioning in seed plants. Science 295:1517-1520

Enquist BJ, Sanderson J, Weiser MD (2002) Modeling macroscopic patterns in ecology. Science 295:1835-1836

Enquist BJ, West GB, Brown JH (2009) Extensions and evaluations of a general quantitative theory of forest structure and dynamics. PNAS 106:7046-7051

Fan R, Sun J, Yang F, Li M, Zheng Y, Zhong Q, Cheng D (2017) Divergent scaling of respiration rates to nitrogen and phosphorus across four woody seedlings between different growing seasons. Ecol Evol 7:8761-8769

Glazier DS (2005) Beyond the '3/4-power law': variation in the intra- and interspecific scaling of metabolic rate in animals. Biol Rev 80:611-662

Glazier DS (2006) The 3/4-power law is not universal: evolution of isometric, ontogenetic metabolic scaling in pelagic animals. Bioscience 56:325-332

Glazier DS (2010) A unifying explanation for diverse metabolic scaling in animals and plants. Biol Rev 85:111-138

Glazier DS (2014) Scaling of metabolic scaling within physical limits. Systems 2: $425-450$

Glazier DS (2015) Is metabolic rate a universal 'pacemaker'for biological processes? Biol Rev 90:377-407

Hamilton MJ, Davidson AD, Sibly RM, Brown JH (2011) Universal scaling of production rates across mammalian lineages. Proc R Soc B-Biol Sci 278:560-566

Hanson PJ, Edwards NT, Garten CT, Andrews JA (2000) Separating root and soil microbial contributions to soil respiration: a review of methods and observations. Biogeochemistry 48:115-146

Hertel D, Leuschner C (2002) A comparison of four different fine root production estimates with ecosystem carbon balance data in a Fagus-Quercus mixed forest. Plant Soil 239:237-251
Huston MA, Wolverton S (2009) The global distribution of net primary production: resolving the paradox. Ecol Monogr 79:343-377

Isaac NJ, Carbone C (2010) Why are metabolic scaling exponents so controversial? Quantifying variance and testing hypotheses. Ecol Lett 13:728-735

Ishida A, Yazaki K, Hoe AL (2005) Ontogenetic transition of leaf physiology and anatomy from seedlings to mature trees of a rain forest pioneer tree, macaranga gigantea. Tree Physiol 25:513-522

Jackson RB, Mooney HA, Schulze ED (1997) A global budget for fine root biomass, surface area, and nutrient contents. PNAS 94:7362-7366

Jenkins DG (2015) Estimating ecological production from biomass. Ecosphere 6:49

Jenkins DG, Haberl H, Erb KH, Nevai AL (2020) Global human "predation" on plant growth and biomass. Glob Ecol Biogeogr 29:1052-1064

Jenkins DG, Pierce S (2017) General allometric scaling of net primary production agrees with plant adaptive strategy theory and has tipping points. J Ecol 105 1094-1104

Kerkhoff AJ, Fagan WF, Elser JJ, Enquist BJ (2006) Phylogenetic and growth form variation in the scaling of nitrogen and phosphorus in the seed plants. Am Nat 168:E103-E122

Kleiber M (1932) Body size and metabolism. Hilgardia 6:315-353

Kozłowski J, Konarzewski M (2004) Is West, Brown and Enquist's model of allometric scaling mathematically correct and biologically relevant? Funct Ecol 18:283-289

Legendre P (2008) Lmodel2: Model II regression. R package version 2.10.1. https://pdfs. semanticscholar.org/1ca0/6cf79eb43d1953396267a3b34aa3a6bdb46a.pdf?_ga=2.14 8187127.1764153728.1599553215-1168478842.1592305636. Accessed 27 Feb 2020

Li HT, Han XG, Wu JG (2005) Lack of evidence for 3/4 scaling of metabolism in terrestrial plants. J Integr Plant Biol 47:1173-1183

Li HT, Han XG, Wu JG (2006) The variant scaling relationship for mass-density across tree-dominated communities. J Integr Plant Biol 48:268-277

Lin Y, Berger U, Grimm V, Huth F, Weiner J (2013) Plant interactions alter the predictions of metabolic scaling theory. PLoS One 8:e0057612

Lomolino MV (2000) Ecology's most general, yet protean pattern: the speciesarea relationship. J Biogeogr 27:17-26

Marba N, Duarte CM, Agusti S (2007) Allometric scaling of plant life history. PNAS 104:15777-15780

Marsden C, Nouvellon Y, Epron D (2008) Relating coarse root respiration to root diameter in clonal Eucalyptus stands in the republic of the Congo. Tree Physiol 28:1245-1254

McCarthy JK, Dwyer JM, Mokany K (2019) A regional-scale assessment of using metabolic scaling theory to predict ecosystem properties. Proc R Soc B Biol Sci 286:e2221

Minden V, Schnetger B, Pufal G, Leonhardt SD (2018) Antibiotic-induced effects on scaling relationships and on plant element contents in herbs and grasses. Ecol Evol 8:6699-6713

Mori S, Yamaji K, Ishida A, Prokushkin SG, Masyagina OV, Hagihara A, Hoque ATMR, Suwa R, Osawa A, Nishizono T, Ueda T, Kinjo M, Miyagi T, Kajimoto T, Koike T, Matsuura Y, Toma T, Zyryanova OA, Abaimov AP, Awaya Y, Araki MG, Kawasaki T, Chiba Y, Umari M (2010) Mixed-power scaling of whole-plant respiration from seedlings to giant trees. PNAS 107:1447-1451

Nadelhoffer KJ, Raich JW (1992) Fine root production estimates and belowground carbon allocation in forest ecosystems. Ecology 73:1139-1147

Nidzieko NJ (2018) Allometric scaling of estuarine ecosystem metabolism. PNAS 115:6733-6738

Niklas KJ (2006) Plant allometry, leaf nitrogen and phosphorus stoichiometry, and interspecific trends in annual growth rates. Ann Bot 97:155-163

Niklas KJ, Enquist BJ (2001) Invariant scaling relationships for interspecific plant biomass production rates and body size. PNAS 98:2922-2927

O'Connor MI, Bernhardt JR (2018) The metabolic theory of ecology and the cost of parasitism. PLoS Biol 16:e2005628

Ogawa K (2019) Scaling relations based on the geometric and metabolic theories in woody plant species: A review. Persp Plant Ecol Evol Syst 40. https://doi. org/10.1016/j.ppees.2019.125480

Oviedo NJ, Newmark PA, Alvarado AS (2003) Allometric scaling and proportion regulation in the freshwater planarian Schmidtea mediterranea. Develop Dyn 226:326-333

Pavon NP (2005) Biomass and root production of two plant life forms in a semiarid mexican scrub: responses to soil nitrogen availability. Can J Bot 83:1317-1321

Peng YH, Niklas KJ, Reich PB, Sun SC (2010) Ontogenetic shift in the scaling of dark respiration with whole-plant mass in seven shrub species. Funct Ecol 24:502-512

Pettersen AK, White CR, Bryson-Richardson RJ, Marshall DJ (2019) Linking lifehistory theory and metabolic theory explains the offspring size-temperature relationship. Ecol Lett 22:518-526 
Pregitzer KS, Laskowski MJ, Burton A, Lessard VC, Zak DR (1998) Variation in sugar maple root respiration with root diameter and soil depth. Tree Physiol 18:665-670

Reich PB, Tjoelker MG, Machado JL, Oleksyn J (2006) Universal scaling of respiratory metabolism, size and nitrogen in plants. Nature 439:457-461

Reich PB, Tjoelker MG, Machado J-L, Oleksyn J (2007) Does the exception prove the rule? Reply Nat 445:E10-E11

Reich PB, Tjoelker MG, Pregitzer KS, Wright IJ, Oleksyn J, Machado JL (2008) Scaling of respiration to nitrogen in leaves, stems and roots of higher land plants. Ecol Lett 11:793-801

Rohlf FJ, Sokal RR (1981) Biometry: the principles and practices of statistics in biological research, 3rd edn. Freeman, New York

Rosenzweig ML (1995) Species diversity in space and time. Cambridge University Press, UK Rubner M (1883) Uber den einfluss der korpergrosse auf stoff und kraftwechsel. Zeitschriftfur Biologie 19:535-562

Rudgers JA, Hallmark A, Baker SR, Baur L, Hall KM, Litvak ME, Muldavin EH, Pockman WT, Whitney KD (2019) Sensitivity of dryland plant allometry to climate. Funct Ecol. https://doi.org/10.1111/1365-2435.13463

Ryan MG, Binkley D, Fownes JH, Giardina CP, Senock RS (2004) An experimental test of the causes of forest growth decline with stand age. Ecol Monogr 74:393-414

Savage VM, Deeds EJ, Fontana W (2008) Sizing up allometric scaling theory. PLoS Comput Biol 4:e1000171

Schenk HJ, Jackson RB (2002) The global biogeography of roots. Ecol Monogr 72: 311-328

Sibly RM, Brown JH, Kodric-Brown A (2012) Metabolic Ecology: A Scaling Approach. Wiley-Blackwell, Oxford

Slot M, Rey-Sanchez C, Winter K, Kitajima K (2014) Trait-based scaling of temperature-dependent foliar respiration in a species-rich tropical forest canopy. Funct Ecol 28:1074-1086

Starko S, Martone PT (2016) An empirical test of 'universal' biomass scaling relationships in kelps: evidence of convergence with seed plants. New Phytol 212:719-729

Strauss K, Reinhold K (2010) Scaling of metabolic rate in the lesser wax moth Achroia grisella does not fit the 3/4-power law and shows significant sex differences. Physiol Entomol 35:59-63

Vogt KA, Vogt DJ, Bloomfield J (1998) Analysis of some direct and indirect methods for estimating root biomass and production of forests at an ecosystem level. Plant Soil 200:71-89

Vogt KA, Vogt DJ, Palmiotto PA, Boon P, Ohara J, Asbjornsen H (1996) Review of root dynamics in forest ecosystems grouped by climate, climatic forest type and species. Plant Soil 187:159-219

West GB, Brown JH (2005) The origin of allometric scaling laws in biology from genomes to ecosystems: towards a quantitative unifying theory of biological structure and organization. J Exp Biol 208:1575-1592

West GB, Brown JH, Enquist BJ (1997) A general model for the origin of allometric scaling laws in biology. Science 276:122-126

West GB, Brown JH, Enquist BJ (1999) A general model for the structure and allometry of plant vascular systems. Nature 400:664-667

West GB, Brown JH, Enquist BJ (2001) A general model for ontogenetic growth. Nature 413:628-631

West GB, Enquist BJ, Brown JH (2009) A general quantitative theory of forest structure and dynamics. PNAS 106:7040-7045

White CR (2010) There is no single $p$. Nature 464:691-693

Yates MC, Glaser D, Post J, Cristescu ME, Fraser DJ, Derry AM (2020) Allometric scaling strengthens the relationship between eDNA particle concentration and organism abundance in nature. BioRxiv. https://doi.org/10.1101/2020.1101.1118.908251

Yoshikawa T, Kawakami K, Masaki T (2019) Allometric scaling of seed retention time in seed dispersers and its application to estimation of seed dispersal potentials of theropod dinosaurs. Oikos 128:836-844

Yuan ZY, Chen HYH (2010) Fine root biomass, production, turnover rates, and nutrient contents in boreal forest ecosystems in relation to species, climate, fertility, and stand age: literature review and meta-analyses. Crit Rev Plant Sci 29:204-221

Yuan ZY, Chen HYH (2012a) A global analysis of fine root production as affected by soil nitrogen and phosphorus. Proc R Soc B-Biol Sci 279:3796-3802

Yuan ZY, Chen HYH (2012b) Indirect methods produce higher estimates of fine root production and turnover rates than direct methods. PLoS One 7:e48989

Yuan ZY, Chen HYH (2015) Decoupling of nitrogen and phosphorus in terrestrial plants associated with global changes. Nat Clim Chang 5:465-469

Yuan ZY, Chen HYH, Reich PB (2011) Global-scale latitudinal patterns of plant fine-root nitrogen and phosphorus. Nat Commun 2:e1346

Yuan ZY, Shi XR, Jiao F, Han FP (2018) Changes in fine root biomass of Picea abies forests: predicting the potential impacts of climate change. J Plant Ecol 11:595-603

\section{Submit your manuscript to a SpringerOpen ${ }^{\circ}$ journal and benefit from:}

- Convenient online submission

- Rigorous peer review

- Open access: articles freely available online

High visibility within the field

- Retaining the copyright to your article

Submit your next manuscript at $\boldsymbol{\nabla}$ springeropen.com 